\title{
Eastern Baltic cod: perspectives from existing data on processes affecting growth and survival of eggs and larvae
}

\author{
Brian MacKenzie $^{1, *}$, Mike St. John ${ }^{1}$, Kai Wieland ${ }^{2}$ \\ ${ }^{1}$ Danish Institute for Fisheries Research, Charlottenlund Castle, DK-2920 Charlottenlund, Denmark \\ ${ }^{2}$ Institut für Meereskunde an der Universität Kiel, Dusternbrooker Weg 20, D-24105 Kiel, Germany
}

\begin{abstract}
We review eastern Baltic cod literature to identify areas for future research involving egg and larval stages. Egg and larval abundances have been estimated for several decades in all of the major spawning areas. Using a subset of the available data we show that the timing of peak egg abundance in one of these areas (Bornholm Basin) varies seasonally by at least 2 mo. Trends in egg and larval abundance over time are not obvious due to differences in gear type, sampling intensity, and survey timing relative to spawning dates. Interannual differences in larval transport away from spawning areas may also contribute to variability in abundance estimates. The results of broad-scale zooplankton surveys suggest that the abundance and types of potential prey in the Baltic Sea are similar to those in other regions and perhaps suitable for moderate-to-fast larval growth. However, few systematic surveys have described food concentrations at appropriate scales for cod larvae, and the species composition of larval diets is unknown. Growth rates for Baltic cod larvae have not been measured and cannot be compared with rates in other areas or to variations in biotic and abiotic factors. Large gaps exist in our knowledge of processes affecting egg and larval growth and survival, but some promising areas of research are indicated. In particular the seasonality of spawning, deep water oxygen concentrations, predation on eggs, and larval food production require further investigation.
\end{abstract}

KEY WORDS: Baltic cod · Eggs - Larvae - Environmental conditions P Population structure - Oxygen Zooplankton

\section{INTRODUCTION}

The cod population in the eastern Baltic Sea (Fig. 1, ICES subdivisions $25-32$ ) is historically one of the largest in the North Atlantic region (Dickson \& Brander 1993) and is presently being commercially exploited by 8 countries (ICES 1994a). The long-term mean abundance is 400000 to 500000 t of spawning stock biomass, but the stock decreased from $>800000$ to $<80000 \mathrm{t}$ from 1980 to 1992 (ICES 1994a). Reasons for this decrease in abundance include high fishing mortality and deterio-

·E-mail: brm@dfu.min.dk rating environmental conditions experienced during the early life stages (Bagge et al. 1994).

In this report we discuss the ecology of the egg and larval stages of Baltic cod, and how environmental factors affecting these stages can contribute to fluctuations in stock biomass. The geographic focus of our discussion is the eastern part of the Baltic Sea and in particular the Bornholm Basin (Fig. 1). This area is considered to be the most important spawning site in the Baltic Sea (Bagge et al. 1994). Environmental conditions in and interactions with neighboring spawning areas (e.g. Gdansk and Gotland Basins) are also considered, as this information can help interpret recent trends within the Bornholm Basin. 


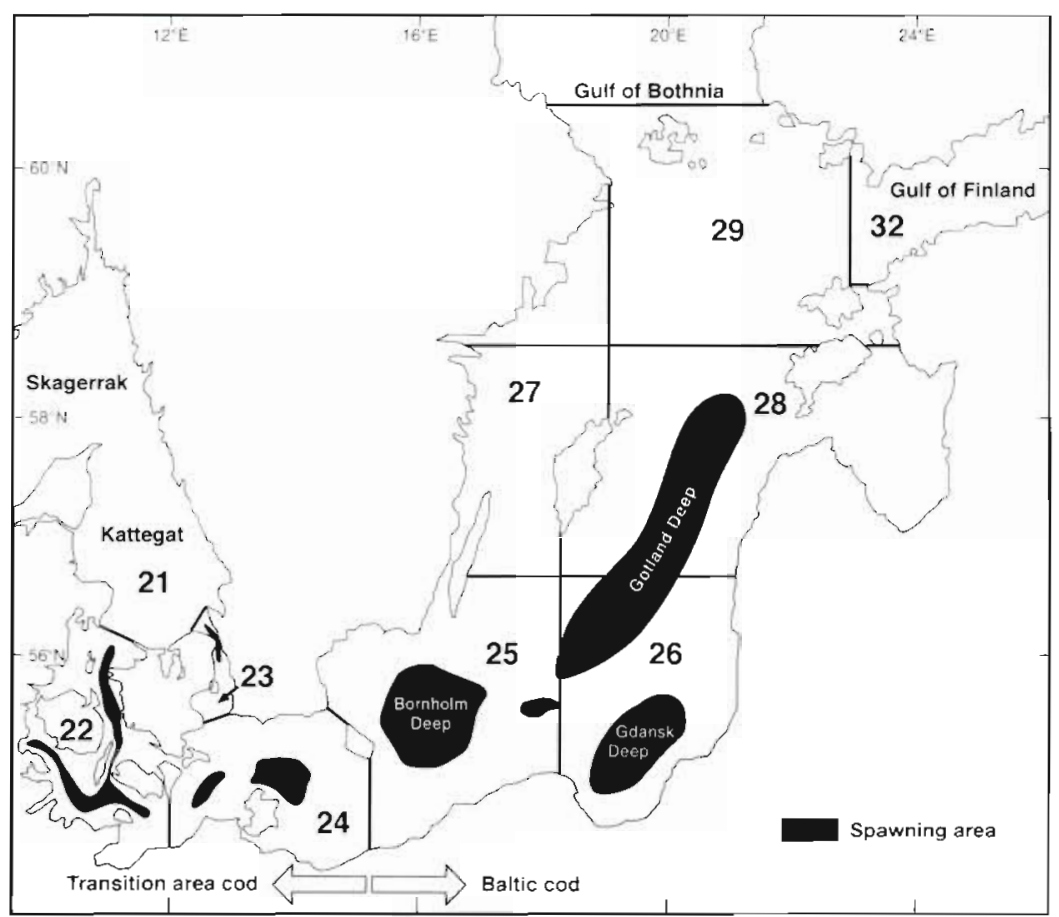

Fig. 1. Map of Baltuc Sea showing ICES subdivisions and principle cod spawning sites in the eastern region. Modified from Bagge et al. (1993)

(Fig. 2B) in order to coincide with the assumed peak in spawning activity. The overall results of these surveys show that average egg abundance in the Bornholm Basin is $35 \mathrm{~m}^{-2}$ ( $\mathrm{SD}=$ $29 \mathrm{~m}^{-2}$; Fig. 2). The abundance and survival of eggs spawned in the Gdansk and Gotland Basins is lower partly because oxygen and salinity conditions limit egg survival. (Plikshs et al. 1993, Nissling et al. 1994, Wieland et al. 1994; details below). Larval abundances in the Bornholm Basin (mean = ca $3 \mathrm{~m}^{-2}$; $\mathrm{SD}=5.8 \mathrm{~m}^{-2}$ ) are approximately 10 -fold less than those of eggs.

The abundance of both eggs and larvae appears to have decreased during recent years (Fig. $3 \mathrm{~A}$ ) along with the decline in spawning stock biomass (Plikshs et al. 1993). In other areas, temporal patterns in egg or larval abundance can provide early measures of potential recruitment to a population (e.g. Brander \& Houghton 1982) and provide independent validations of virtual population analysis (VPA) estimates of spawning

Our objective is to develop new hypotheses of how environmental variability and the spawning stock interact to determine recruitment levels of cod in the eastern Baltic Sea. The approach we use is multi-disciplinary and comprises a review and integration of literature relating to the early life stages. We combine data extracted from different sources to draw conclusions and to suggest possible productive research topics.

\section{INTERANNUAL VARIABILITY IN EGG AND LARVAL ABUNDANCE}

The distribution and abundance of eggs and larvae in the eastern Baltic Sea has been investigated since the 1930s (Bagge et al. 1994; Figs. 2 \& 3). These studies have identified the Bornholm, Gdansk, and Gotland Basins, and to a lesser extent the Slupsk Furrow as the main spawning sites (Aro 1989, Bagge et al. 1994). Spawning takes place in deep water and eggs develop at depths of 50 to $80 \mathrm{~m}$ depending on egg buoyancy (Wieland 1988, Wieland \& Zuzarte 1991, Nissling et al. 1994). Larvae are usually found closer to the surface in fresher water, but below the summer thermocline (Poulsen 1931, Müller 1988, Wieland \& Zuzarte 1991, Gronkjæer et al. 1995)

Most surveys for cod eggs and larvae in the eastern Baltic Sea have been conducted during April and May stock biomass (Heessen \& Rijnsdorp 1989, Heath 1993). However, in the eastern Baltic Sea, it is presently difficult to assess whether and by how much the temporal variability in egg and larval abundances is artifactual (e.g. due to variability in timing and duration of spawning relative to survey timing, survey methods) or real (e.g. due to lower annual egg production rates, or changing environmental conditions).

One sampling artifact likely to be responsible for some of the variability in egg and larval abundances is survey timing relative to the onset and duration of spawning. Cod in the eastern Baltic Sea have one of the longest (6 to $8 \mathrm{mo}_{\text {; }}$ Uzars et al. 1991, Linkowski \& Kowalewska-Pahlke 1993, Bagge et al. 1994) and most variable spawning periods of any cod population in the North Atlantic region (ICES 1994b). However, in some years, surveys have been conducted over periods of only 1 to 3 mo. Hence, this survey strategy, which may be appropriate for other fish populations, does not consistently sample the main spawning period for eastern Baltic cod on an annual basis, and contributes variability to egg and larval abundance estimates independently of total annual egg production rate.

To il]ustrate part of the variability in spawning activity as inferred by egg abundances, we have selected 13 yr from the data compiled in Fig. 2 for which at least 3 surveys were conducted over a period of at least $60 \mathrm{~d}$. Within most of these years, 1 or 2 collaborating insti- 


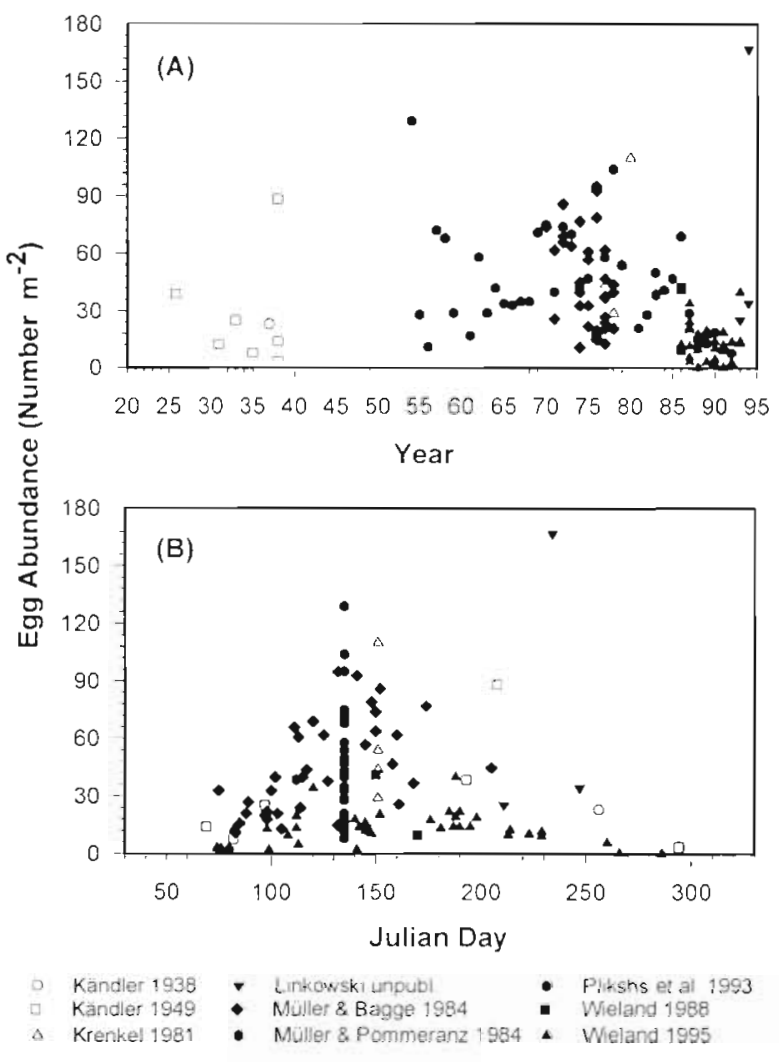

Fig. 2. Abundance of cod eggs in the Bornholm Basin by (A) year and $(B)$ day number as estimated by different investigators. Data points are mean values of several tows withın a survey. Sampling times are represented as midpoints of survey periods

tutes conducted all of the sampling, which reduces the possibility of gear-induced biases. For these $13 \mathrm{yr}$, there were on average 6.3 surveys per year, and $106 \mathrm{~d}$ between midpoints of the first and last surveys within each year The seasonality of egg abundance among these years shows several patterns (Fig. 4).

First, in 11 of these years, measured egg abundances first increase and then decrease, suggesting that the sampling campaign overlapped the peak spawning period. Second, in 2 years there is either an increase (1992; Fig. 4D) or a decrease (1986; Fig. 4C) in egg abundance over the sampling period. This suggests that the peak in spawning activity was actually outside the survey period. The third pattern is that the date corresponding to maximal mean egg abundance within a survey varies by several months. The mean and SD calendar day of peak spawning for these 13 years is $156 \pm 31.5$. Note that the variability in peak spawning date is likely somewhat larger because we assumed that for the 2 years having truncated survey data $(1992,1986)$, the peak spawning date corresponded exactly to the dates having highest egg abundance.

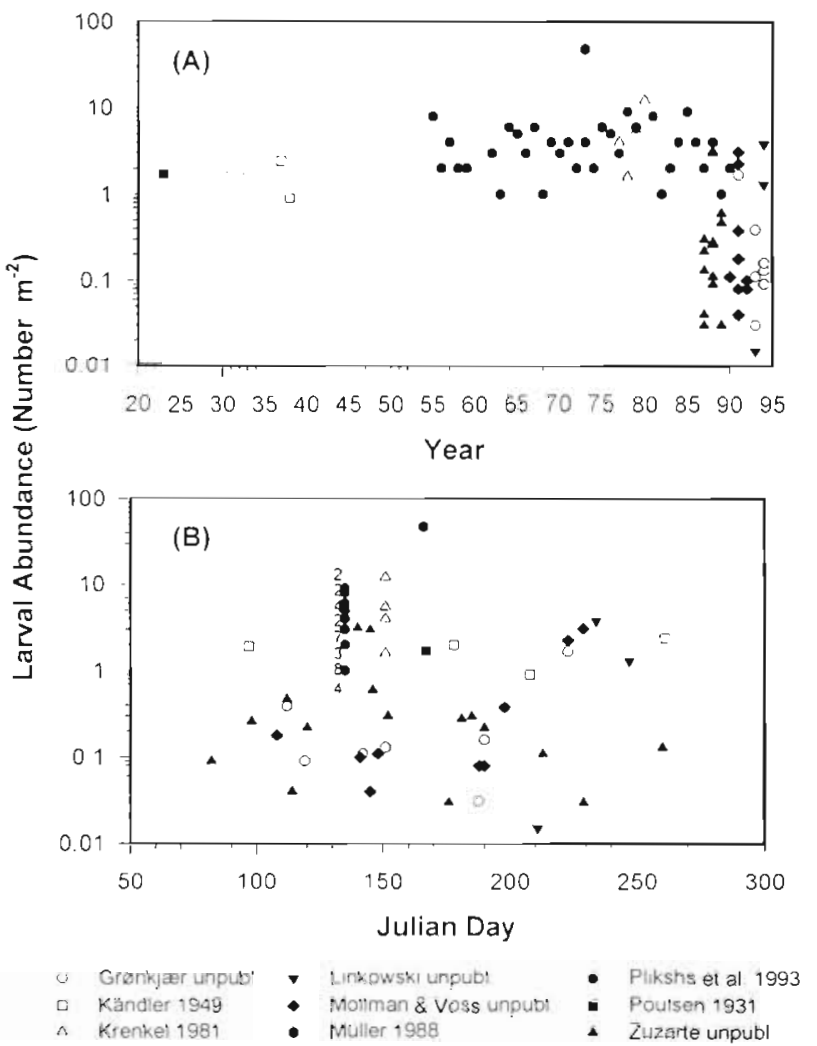

Fig. 3. Abundance of cod larvae in the Bornholm Basin by (A) year and (B) day number as estimated by different investigators. Data points are mean values of several tows within a survey. Sampling tımes are represented as midpoints of survey periods. Inside $(B)$, numbers represent the number of years for given larval abundance

We conclude that variability in timing of spawning relative to survey timing is probably a major source of variability in the egg and larval estimates, and will likely confound attempts to use egg or larval abundances to explain variance in other variables (e.g. recruitment, spawning stock biomass). For example, during the years of highest population egg production in the eastern Baltic Sea (1979 to 1985; Fig. 5), we have identified only 1.1 egg survey per year for the Bornholm Basin (i.e. Krenkel 1981, Plikshs et al. 1993). Surveys during these years were conducted in the spring (April to June) and indicate that egg abundance (ca $40 \mathrm{~m}^{-2}$ ) was close to the long-term mean, even though population egg production for the eastern Baltic Sea during these years exceeded the 1974 to 1993 mean by about $70 \%\left(2.2 \times 10^{14}\right.$ vs $1.4 \times 10^{14}$ eggs $\mathrm{yr}^{-1}$ ). It is possible therefore that within some of those years, egg abundances were still increasing over the 3 mo sampling period, and that if additional surveys had been conducted at other times during these years, they might have detected higher egg abundances. 


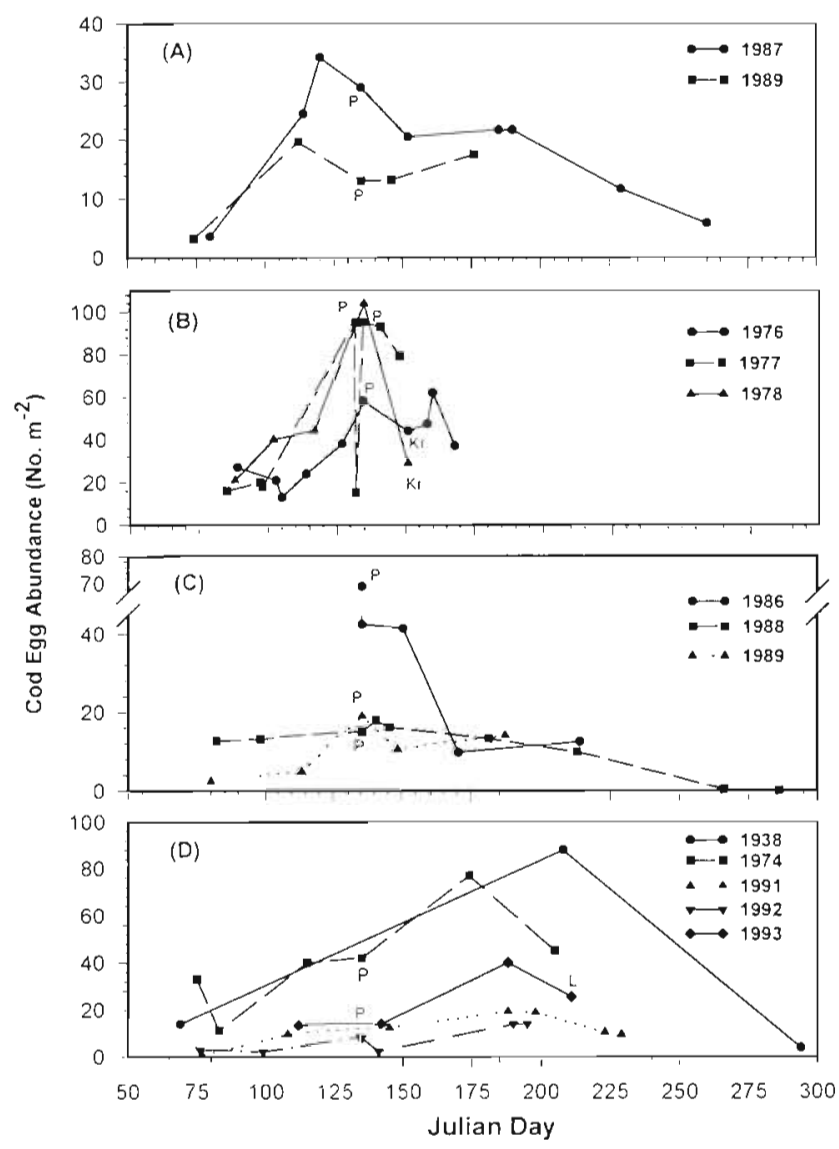

Fig. 4. Interannual differences in cod egg abundance for 13 years when there were at least $60 \mathrm{~d}$ between midpoints of the furst and last surveys within a year. Data sources: (A) Wieland (1995); (B) Müller \& Bagge 1984; (C) Wieland (1988, 1995); (D) Kändler (1949) for 1938 data, Müller \& Bagge (1984) for 1974 data and Wieland (1995, unpubl.) for 1991-1993 data. Letters on panels indicate additional surveys conducted by Plikshs et al. (1993) (P), Krenkel (1981) (Kr), and Linkowski (unpubl.) (L)

Based on the considerations outlined above, we suggest 2 activities that might improve the quality of information extractable from historical and future egg and larval abundance estimates. First, an independent time series of peak spawning dates should be sought from other data sources such as (1) gonad maturity indices from research vessel trawl surveys (Bagge \& Steffensen 1991, Uzars et al. 1991\}, (2) seasonal distributions of larval sizes or proportions of larvae with and without yolk sacs, or (3) cod roe sales (Pedersen 1984, i Jakupsstovu \& Reinert 1994). This could give information about the seasonality of spawning in other years, improve our preliminary spawning date distribution derived above, and perhaps help correct egg and larval abundances in years when sampling effort did not overlap the entire sampling period. Secondly, the seasonal coverage of any new egg and gonad maturity surveys could be coordinated internationally to cover the whole range of spawning times.

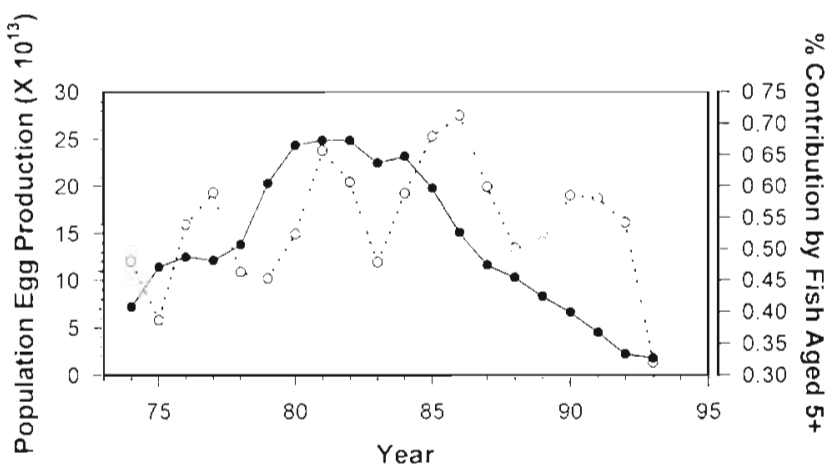

Fig. 5. Annual population egg production for cod in ICES subdivisions $25-32(\bullet)$ and the proportion of this production contributed by cod aged $5+$ in different years (0). Population numbers and weight-at-age data from ICES (1994a). Sex ratio by age, $\%$ mature-at-age, and body weight-individual fecundity data were obtained from Berner \& Vaske (1981), Weber

(1989), and Kosior \& Strzyzewska (1979) respectively

A second artifact that can contribute to the intra- and interannual variability in the egg and larval estimates is differences in sampling methods. For example, gear types, depth strata and sampling intensity (numbers of sampled stations per year $=c a 7$ to 45 ) differ between studies. Thirdly, most studies have not distinguished between the different developmental stages and sizes of sampled eggs and larvae, so it is possible that some of the variability in Figs. $2 \& 3$ is due to the inclusion of both early and late stages of eggs, or small and larger larvae. The influence of these 2 additional factors on abundance estimates can perhaps be reduced after calibration between studies, or by conducting analyses with carefully selected data (e.g. estimates based on 1 gear type or based on a minimum number of stations at a given time of year).

\section{SPAWNING STOCK BIOMASS, ANNUAL EGG PRODUCTION, AND EGG QUALITY}

In principle the major factor affecting interannual abundance of eggs and larvae in the spawning areas should be the number of eggs produced by spawning adults. However, it is difficult to derive accurate estimates of annual egg production for the Baltic Sea because some of the required input parameters (e.g. body size-fecundity relationships) are based on small data sets (Bagge et al. 1994). In particular, egg production model inputs may not match the true population characteristics in years and places not covered by the original sampling used to estimate these inputs. In addition. it is likely that some inputs may be more variable among years than others, and that some have more influence on annual egg production than others. Hence, 

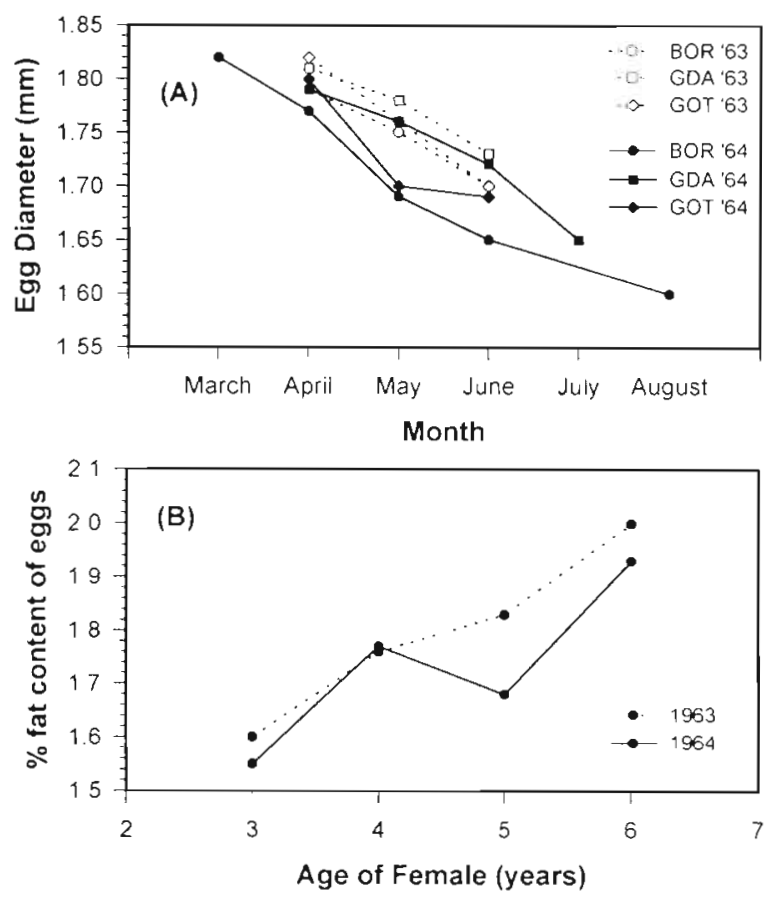

Fig. 6. (A) Mean egg diameter of cod eggs in ichthyoplankton samples from different spawning areas and months during 1963 and 1964. BOR: Bornholm Basin; GDA: Gdansk Basin; GOT. Gotland Basin. (B). Percentage of fat content relative to live weight in stage IV cod eggs from females of different ages during 1963 and 1964. All data from Grauman (1965)

a sensitivity analysis of annual egg production estimates to variation in input parameters could be useful. This exercise would accomplish 2 tasks: (1) acknowledge some of the uncertainty in annual egg production estimates, and (2) identify which parameters have the most influence on egg production, and therefore which ones are most worthy of further investigation.

Another variable that should be included in attempts to estimate egg production is the influence of parental characteristics on survival probability of eggs. It is becoming increasingly evident that egg survival within a population is not random, but varies systematically with parental reproductive history. For example. in Norwegian coastal cod, mortality of eggs produced by fish which have spawned in previous years ('repeat spawners') is lower than in fish in their first spawning year ('recruit spawners'; Solemdal et al. 1995). In eastern Baltic cod, egg buoyancy, which affects survival in situ (Nissling et al. 1994, Wieland et al. 1994), varies with batch number within a female (Nissling et al. 1994). In addition, egg size in the 3 main Baltic spawning areas decreases during the spawning season, and older females produce eggs with a higher fat content (Grauman 1965; Fig. 6).

Since egg characteristics such as size and biochemical composition affect aspects of larval feeding and growth (e.g. larval size at hatch, mouth gape, activity levels; Knutsen \& Tilseth 1985, Solemdal et al. 1992, Marteinsdottir et al. 1993), the survival probability of offspring from eastern Baltic cod probably has a significant parental influence. Moreover, there appears to be a cyclic pattern in the relative contribution of older females to population egg production (Fig. 5). If egg survival probability is related to female age, it is possible that years having a high proportion and abundance of older females may have better than average egg survival and recruitment. The timing of spawing of Baltic cod will also affect survival probability because eggs spawned at different times within the year are exposed to different sources and magnitudes of mortality (e.g. low oxygen, predators; see below).

As a consequence, one of the factors that likely contributes variability to the stock-recruitment relationship for Baltic cod is violation of the assumption that all adults produce offspring with equal survival probability, regardless of parental age or condition (e.g. Hutchings \& Myers 1994a). Measures of population egg production that are structured to accommodate differences in egg survival probability (e.g due to differences in spawning date, age and condition of females, rates of atresia; Kjesbu et al. 1991) may provide better estimates of survival and recruitment than spawning stock biomass (Chambers et al. 1989, Kjesbu et al. 1992). Hence, progress in understanding maternal (Chambers et al. 1989) and paternal (Trippel \& Neilson 1992) influences on egg survival probabilities could lead to improved recruitment estimates based on egg production (Kjesbu et al. 1992).

\section{OXYGEN CONDITIONS, SPAWNING DATE VARIABILITY AND PREDATION MORTALITY}

One of the major environmental factors which increases egg mortality rates in the eastern Baltic Sea is low oxygen concentration (Nissling et al. 1994, Wieland et al. 1994). Because of the irregularity of inflows of saline, oxygen-rich water from the North Sea, the oxygen content of the deep water of the eastern Baltic undergoes interannual natural fluctuations (Fig. $7 \mathrm{~A}_{\text {; }}$ Plikshs et al. 1993). In some years, oxygen levels in deep water can decrease to $<2 \mathrm{ml}^{-1}$ (Fig. 7A), at which point laboratory studies show that egg development is prevented (Wieland et al. 1994).

Since cod eggs in the Baltic Sea are negatively buoyant relative to the oxygen-rich surface layer (Nissling et al. 1994), cod eggs will sink to the deeper oxygenpoor layers (Wieland 1988, Wieland et al. 1994). Hence in years when oxygen levels in spawning basins are low, factors which affect cod egg buoyancy (e.g 


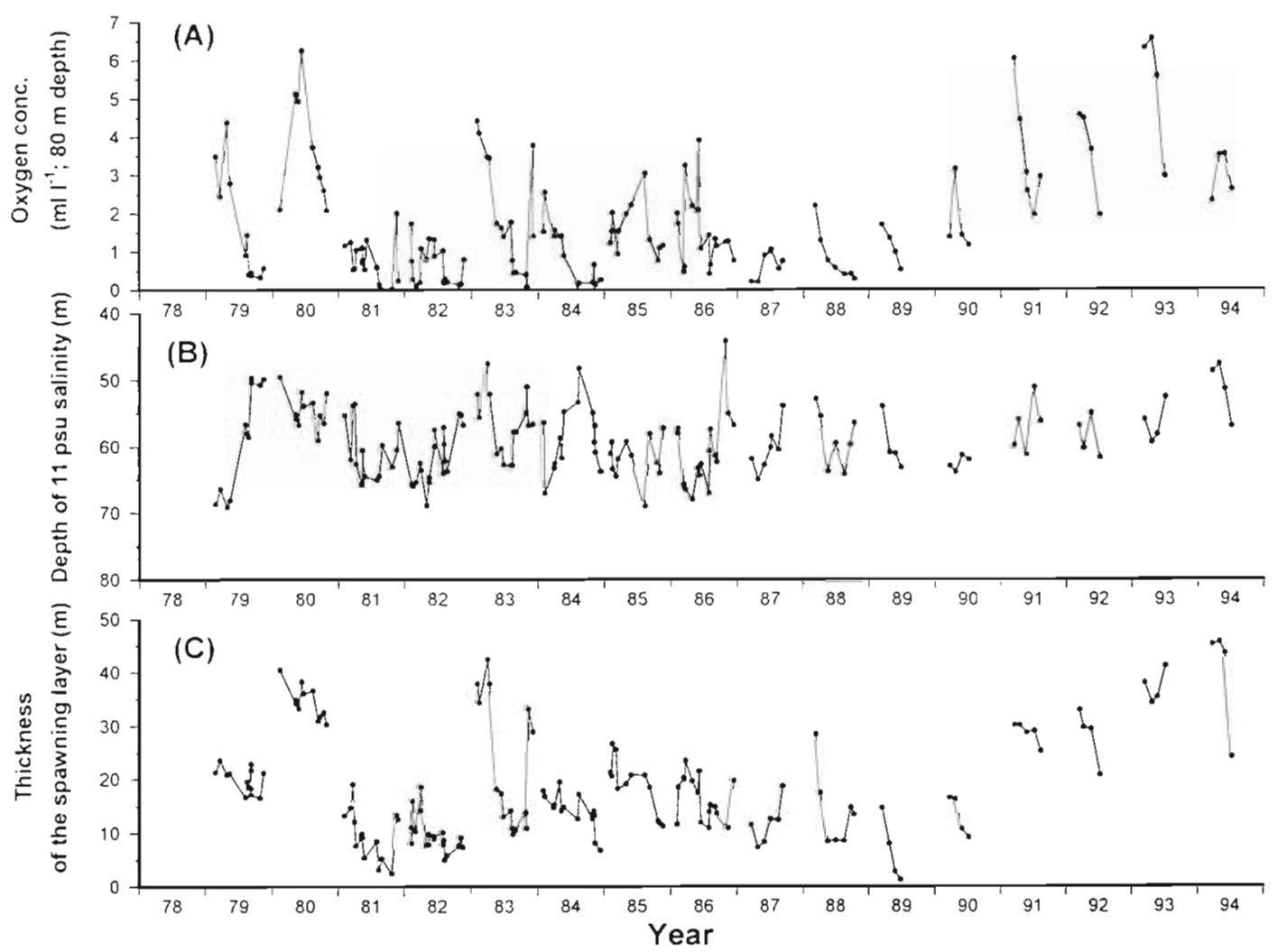

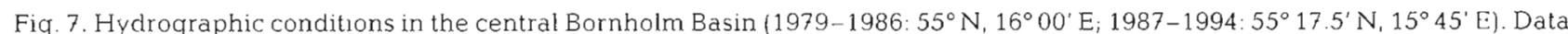
for years 1979-1986, 1987-1992, and 1993-1994 are from HELCOM (1990; monitoring station BY5), Wieland (1995), and Wieland (unpubl.) respectively. (A) Concentration of dissolved oxygen at $80 \mathrm{~m}$ depth. (B) Depth of 11 PSU salinity. (C) Thickness of the spawning layer as defined by water having temperature $>1.5^{\circ} \mathrm{C}$, salınity $>11 \mathrm{PSU}$, and dissolved oxygen concentration $>2 \mathrm{ml}$

female reproductive history) will affect survival rates (Nissling et al. 1994).

Because of the interaction between oxygen conditions and egg buoyancy, estimates of the volume of water suitable for egg development (oxygen content $>2 \mathrm{ml} \mathrm{l}^{-1}$, temperature $>1.5 \mathrm{C}$ and salinity $>11 \mathrm{ppt}$ ) have been made (Plikshs et al. 1993; Fig. 7). These estimates ('reproductive volume' and 'thickness of the spawning layer') show large variability between and within years, and among the 3 main eastern Baltic spawning sites (Fig. 7; Plikshs et al. 1993). However, they have been found to explain a significant portion of the interannual variability in recruitment fluctuations in the eastern Baltic cod stock (Plikshs et al. 1993). In fact, the requirement for a thick spawning layer is so important that the influence of more familiar recruitment processes (e.g. predation) will likely only be evident in years when oxygen levels permit complete egg development (Wieland et al. 1994).

In addition to the role of interannual variability in spawning layer thickness in egg survival, we propose that its seasonal variability also affects egg survival. For example, the time series of reproductive volumes
(Plikshs et al. 1993) and spawning layer thicknesses (Fig. 7C) in the Bornholm Basin clearly show strong intra-annual components, with oxygen levels being higher earlier in the year than later. In addition, it now appears that eutrophication has reduced the impact of deep water renewal on oxygen conditions, so that periods of favorable oxygen content are shorter than in the past (Hansson \& Rudstam 1990, Nissling et al. 1994).

Given the variability in spawning time described above, it is reasonable to hypothesize that if spawning occurs mostly in the early part of a particular year, egg survival rate should be relatively high because of adequate oxygen conditions. However, if spawning occurs mostly in summer, then oxygen conditions will be lower and egg mortality rates are predicted to be higher. Hence, in periods when oxygen conditions throughout the year prevent successful egg development in the Gdansk and Gotland Basins (as they did during much of the 1980s and early 1990s; Plikshs et al. 1993. Nissling et al. 1994), the reproductive success of the entire eastern Baltic population may depend on the likelihood of spawning occurring during the spring in the Bornholm Basin. 
However, superimposed on the interaction between spawning layer thickness, egg survival and spawning time, is the seasonality of predation on eggs and larvae in the Bornholm Basin (Köster \& Schnack 1994). In the years 1987 to 1991, sprat predation on cod eggs was a much larger and more significant component of egg mortality in spring than in summer Herring predation mortality was lower than sprat, but increased from spring to summer Predation mortality of cod larvae by either predator was low throughout the year. Hence, given a scenario in which oxygen conditions vary seasonally (Fig. 7), even if spawning were to occur early in the year (April to June), many eggs would be consumed by sprat, thereby reducing the likelihood that a strong ycarclass would result (Köster \& Schnack 1994). To avoid sprat predation, spawning should be later, but this strategy in a typical year increases the risk of egg mortality due to oxygen stress. In this way, the seasonal patterns of spawning, egg predation, and oxygen-induced egg mortality would appear to greatly reduce the probability that a good yearclass could be produced in a year having marginal or even average oxygen conditions.

We suggest therefore that historical and future patterns of onset and duration of spawning should be identified, as well as the causes of their variability. Based on findings with cod in other areas, the variables that should be considered as possible determinants of peak spawning date include population age and size structure (Kjesbu et al. 199.1, Hutchings \& Myers 1993), water temperature (Brander 1994, Hutchings \& Myers 1994b, Kjesbu 1994), and food conditions (Kjesbu 1994). In addition, the oceanographic factors responsible for the seasonal variability in spawning layer thickness need to be more clearly described, as well as the seasonality of predation mortality on eggs and larvae in the Gdansk and Gotland Basins (Köster \& Schnack 1994).

\section{HYDROGRAPHIC EFFECTS ON ADULT SPATIAL DISTRIBUTIONS AND EGG AND LARVAL TRANSPORT}

\section{General}

The cod population east of Bornholm is considered to be relatively distinct from that to the west because of differences in migration patterns, meristics, and growth rates (Aro 1989, Bagge \& Steffensen 1989, Bagge et al. 1994). As a result, they are considered as 2 separate stocks for stock assessment purposes (ICES 1994a). However, if there occasionally is appreciable exchange of eggs, larvae or adults between the areas, then stock assessments would have to consider rates of immigration and emigration from neighboring areas
Below we consider the role of large-scale hydrographic influences on the distributions of eggs and larvae both within and between the western (Fig. 1; ICES subdivisions 21-24) and eastern Baltic (Fig. 1; ICES subdivisions 25-32). We also evaluate ways in which hydrography could affect the distribution of adults, and therefore reproductive output, among spawning sites in the eastern Baltic Sea.

\section{Effects of inflowing North Sea water on transport of eggs and larvae to the eastern Baltic Sea}

The dominant physical oceanographic feature of the entire Baltic Sea is a large-scale surface outflow of fresh water, counterbalanced by irregular inflows of saline North Sea water along the bottom (Kullenberg \& Jacobsen 1981, Moller \& Hansen 1994). The intensity and frequency of the inflows depend on meteorological conditions and therefore vary greatly within and among years (Matthaus \& Franck 1992). This has led some investigators to suggest that inflows could be a means of egg and larval exchange within various parts of the Baltic Sea (Poulsen 1931, Bagge 1981, Westerberg 1994)

However, if these inflows represent an important mechanism by which eggs can be transported into the eastern Baltic Sea, there must be temporal and spatial overlap between eggs and the inflowing water mass. Therefore, the timing and duration of inflows must approximately match the known spawning times of cod in potential donor populations if transport of eggs or larvae into the eastern Baltic Sea is to occur. In this context, we shall consider only the 'major inflows' (Matthaus \& Franck 1992) as potentially contributing to the egg and larval supply of the eastern Baltic Sea because only these inflows have strong enough intensities to exert a measurable influence on abiotic conditions in the eastern areas (Matthaus \& Frank 1992).

We note that most $(62.5 \%)$ of the major inflows recorded between 1897 and mid 1993 occurred between November 1 and January 31, and that 11 of the 14 most intensive inflows occurred between November 1 and January 31 (Matthaus 1993). The duration of an inflow event is 5 to $29 \mathrm{~d}$ (mode $=7.5 \mathrm{~d}$; Matthaus \& Franck 1992). By the time the incoming water reaches the recording site at Gedser Rev (Fig. 1; western Baltic Sea i subdivision 24), the water has been flowing for about 1 wk (modal inflow duration; Matthaus \& Franck 1992). As a result, an inflow event recorded at Gedser Rev, for example, on January 15 suggests that a potential donor cod population (e.g. in the Belt Sed or Kattegat) must spawn in early to mid January if its eggs are to be transported southwards past the recording station by inflowing bottom water. If inflow events were to 
transport past the recording station any newly hatched larvae that hatched as eggs in the Belt Sea or Kattegat, the estimated spawning dates would have to be at least 3 wk earlier, assuming egg development times of Wieland et al. (1994) for winter water temperatures $\left(3^{\circ} \mathrm{C}\right)$ typical for the Kattegat-Belt Sea-western Baltic Sea region.

The required spawning dates (December and January) for egg or larval transport by a January inflow event appear to be at least 1 mo earlier than the observed peak spawning dates for the Skagerrak, Kattegat and Belt Sea cod populations (Table 1), and the North Sea population (central part: mid February; northern part: April; Brander 1993). Thus most spawning in possible source populations appears to occur after the termination point of most of the observed major inflow events. For example, there were only 2 intense inflows between 1897 and 1993 during February to April (Matthaus \& Franck 1992) when cod spawning activity is greatest among the possible donor populations. This indicates that cod eggs and larvae from the Skagerrak, Kattegat and Belt Sea are unlikely to be transported into the eastern Baltic Sea by major Baltic inflow events.

But even if some transport was given, the egg or Jarval contribution that source populations could make to that in the eastern Baltic Sea would seem to be small. Mean spawning stock biomasses (VPA estimates) of the likely source populations are low compared to that in the eastern Baltic Sea (Table 1). The amount of egg production in donor areas is unlikely to make a significant impact on the abundance of eggs in the eastern Baltic Sea.

In summary, given the long-term seasonal distributions of major inflow events and spawning times, the transport of eggs and larvae into the eastern part of the Baltic Sea is not likely to occur during most years. We conclude that even if a transport of eggs and larvae does occur from the western Baltic Sea, it is unlikely to have a major effect on recruitment to the cod population in the eastern Baltic. These considerations, however, do not preclude local exchange of eggs and larvae between adjacent areas (e.g Poulsen 1931,
Westerberg 1994) that could be mediated by weaker inflows. Such inflows must occur at depths that match the vertical distribution of eggs and or larvae. For example, 20 to $25 \%$ of the total annual egg production of subdivisions 22 to 24 (Fig. 1) is believed to have been carried through the Øresund and Great Belt towards the Arkona Basin by such events in the spring of 1993 (Westerberg 1994)

\section{Effects of wind-induced transport on egg and larval distributions}

In the eastern Baltic Sea, circulation patterns in the upper layer of the Baltic are dominated by wind conditions (Kullenberg \& Jacobsen 1981, Moller \& Hansen 1994). However, cod eggs are generally located near the permanent halocline at depths of 50 to $70 \mathrm{~m}$ and below the sill depths (Wieland et al. 1994). Because they are below the depths most likely influenced by wind-induced circulations, eggs are retained within the spawning areas (e.g. Wieland 1988)

After hatching, larvae rise towards shallower depths, where they are more likely to be influenced by windinduced currents. However, even if larvae remain at or below the summer thermocline, they can occasionally be exposed to strong wind-induced currents as a result of Ekman dynamics (Krauss \& Brügge 1991). Model simulations of interannual variability in wind-induced transport are now being used to assess some of the possible routes of larval drift in the Baltic (Aro et al. 1991, Hinrichsen et al. 1995). Simulated drift trajectories and field sampling for larvae hatched in the Bornholm Basin show that even under relatively calm wind conditions larvae can be transported away from the spawning site (Hinrichsen et al. 1995).

Modeling efforts such as these are rapidly becoming more sophisticated. State-of-the-art models which now describe Baltic circulation in 3 dimensions (Funkquist 1993, Lehman 1995) can potentially be coupled with appropriate biological inputs to estimate primary production rates (e.g. St. John et al. 1993). Larval drift models for cod in other areas have been combined. with individual-

Table 1. Timing of peak spawning and long-term spawning stock biomasses (mean and SD) of potential source populations of cod eggs and larvae to the eastern Baltic Sea

\begin{tabular}{|lcccc|}
\hline Region & Month & Data source & Spawning stock biomass (t) & Data source \\
\hline Skagerrak & Feb-Mar & Poulsen (1931) & $22400 \pm 5300$ & ICES (1994C) \\
Kattegat & Mar & Poulsen (1931) & $23500 \pm 14200$ & ICES (1993) \\
Western Baltic (Subdivisions 22, 24) & Feb-Mar & Bagge et al. (1994) & $33000 \pm 12400$ & ICES (1994a) \\
Eastern Baltic (Subdivisions 25-32) & Mar-Aug & Brander (1993) & $467000 \pm 243000$ & ICES (1994a) \\
\hline
\end{tabular}


based larval feeding and growth models (Werner et al. 1996), and have proven valuable for estimating egg and larval retention rates (de Young \& Davidson 1994) and identifying nursery sites for settled 0 -group cod ( $\AA$ dlandsvik \& Sundby 1994). When coupled with data assimilation techniques and surface drifters, they can be used interactively for realtime tracking of cohorts of drifting larvae (Bowen et al. 1995).

Unfortunately, much of the biological information (e.g. larval vertical distributions, buoyancy) required to apply these models to cod larvae in the eastern Baltic Sea is presently lacking. If such information becomes available, we anticipate that our understanding of processes affecting the distribution and growth of larvae and 0-group cod in the eastern Baltic Sea would be greatly advanced. For example, 2 foreseeable outputs of such an activity could be (1) the identification of 0-group nursery sites based on model outputs of spring and summer drift trajectories from the 3 eastern Baltic spawning sites, and (2) the establishment of an annual autumn 0-group demersal survey whose sampling regions would be guided by modelled drift trajectories. Such a survey could potentially contribute to assessment activities for this population

\section{Effects of North Sea inflows on adult distributions}

Inflows of North Sea water probably have important indirect influences on egg and larval abundances via their effects on adult distributions and spawning migrations within the eastern Baltic. In general, the hydrographic factors affecting migration routes in cod are poorly known (Rose 1994). However, in one area where oxygen concentrations are presumably high [Northwest Atlantic Fisheries Organization (NAFO) region 2J3KL; Newfoundland-Labrador shelf], water temperature is an important factor affecting migration routes (Rose 1994). In the eastern Baltic Sea, it is possible that the wider range of oxygen concentrations, in addition to temperature, will affect migration routes, the choice of spawning sites/depths, and more generally the horizontal and vertical distribution of adult cod (Hansson \& Rudstam 1990, Uzars et al. 1991).

The possibility that North Sea inflows expand the range of adult cod within the Baltic Sea has been investigated earlier (e.g. Poulsen 1931). With respect to cod in the western Baltic Sea, he suggested that inflows allow unusually large numbers of Skagerrak and North Sea cod to reproduce in the southern Kattegat and Belt Sea. To support this suggestion, he shows a positive correlation between the number of larvae in April and May in the Belt Sea and the average salinity of the bottom water at Schultz' Ground (southern Kattegat) during the previous November and December

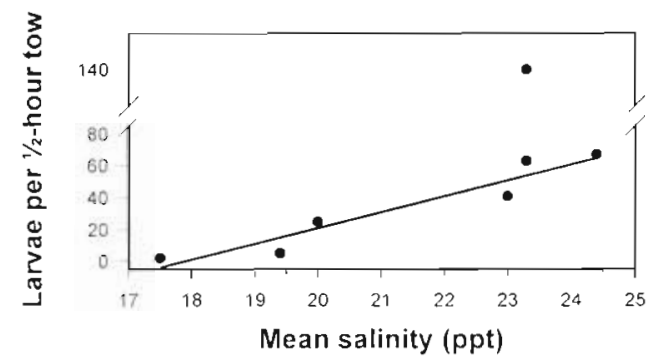

Fig. 8. Relationship between mean bottom salinity at Schultz' Ground (southern Kattegat) during November and December 1922-1928 and the mean abundance of cod larvae in the Belt Sea (ICES subdivision 22) during April and May of the following year (1923-1929). Data from Poulsen (1931, Fig. 43). Regression line for all years is $y=13.7 x-247\left(R^{2}=0.55 ; p=\right.$ $0.06)_{;}$if the outlier year (1923) is excluded the relation becomes $y=9.9 x-178\left(R^{2}=0.91 ; p=0.006\right)$. This line is drawn on the figure

(Fig. 8). Poulsen interpreted this finding as an indication that inflows of saline water, which occur mostly during the autumn and winter (Matthaus \& Franck 1992), expanded the available habitat of cod from northerly areas (e.g. Skagerrak-Kattegat) towards southerly areas (Belt Sea, western Baltic Sea). Conversely, increased survival of eggs and larvae could also have produced this pattern. However, Poulsen (1931) suggested that the annual autumn migration of cod from the Skagerrak and Kattegat into southerly areas could be extended during years having inflows, and that these fish could spawn the following spring before emigrating back to the north. In a similar manner, Johansen (1926) concluded that a large inflow of North Sea water was responsible for extending the southerly and easterly range of Skagerrak and Kattegat populations of haddock (Melanogrammus aeglefinus; Gadidae) into the southern Kattegat, Belt Sea and western Baltic Sea.

By analogy with the effects of inflows on cod and haddock distributions in the western Baltic Sea, we would expect similar effects on adult cod distributions within the eastern Baltic. If this is true, then the relative contributions of the major spawning areas to reproductive and recruitment success will vary among years, not only because low oxygen conditions prevent egg development in some areas (Wieland et al. 1994), but also because some fraction of the population which might normally spawn in a given area may avoid the same area when oxygen conditions are poor. Alternatively, a local cod population could remain in the same area, but spawn in shallower (i.e. fresher) water, which could still reduce reproductive success via lowered egg fertilization rates (Westin \& Nissling 1991).

Existing tagging studies (e.g. Birjukov 1969) reviewed by Aro (1989) do show that eastern Baltic cod 
use different spawning grounds in different years but the reasons for spawning site choice are unknown. A re-analysis of tagging studies and adult spatial distributions with specific reference to the timing, duration and magnitude of inflow events might therefore show how migration routes and destinations vary with hydrographic conditions in the eastern Baltic Sea (Uzars et al. 1991, ICES 1994a). In addition, studies of meristic characters (e.g. vertebral counts; Birjukov 1969) which vary in predictable ways with environmental conditions (e.g oxygen concentrations) during egg and larval development (e.g. Lindsey 1988, Frank 1991), could indicate likely spawning sites and times (i.e. spring or summer) of survivors. This information could help determine how reproductive success varies with environmental conditions as functions of spawning site and date within the eastern Baltic Sea.

\section{FOOD CONDITIONS FOR GROWTH AND SURVIVAL OF LARVAL AND PELAGIC 0-GROUP COD}

The diets and prey characteristics (distributions, concentrations, sizes, biochemical composition) for larval and pelagic 0 -group cod have not been well described for the eastern Baltic Sea. However, in other areas, the diets of cod larvae are dominated by Pseudocalanus sp., Calanus finmarchicus, Acartia sp., Oithona similus, Temora longicornus, and Centropages typicus (Bainbridge \& MacKay 1968, Kane 1984, Sundby \& Fossum 1990, Economou 1991). These same species (except for Calanus finmarchicus; Hernroth \& Ackefors 1979) all regularly occur in the eastern Baltic Sea (e.g. Hernroth \& Ackefors 1979, Ciszewski 1985, Ciszewska 1990). Hence, the taxonomic composition of zooplankton in the eastern Baltic Sea is broadly similar to that in other larval cod nursery areas, and it is possible that larval diets in the eastern Baltic resemble those outside the Baltic

However, if the effects of prey type on larval feeding selectivity are to be understood, or if advanced individual-based drift models of larval feeding and growth (Werner et al. 1996) are to be applied in the eastern Baltic Sea, much more detailed information about larval diets (e.g. prey size and type, seasonal characteristics of the plankton food web) and small-intermediate scale prey distributions (ICES 1994d) will be required.

The quantities of prey in the eastern Baltic Sea that are suitable for larval and pelagic 0 -group cod are difficult to assess. This is because much of the available plankton data (e.g. monitoring studies) has been collected or averaged at large time and space scales which bear little resemblance to prey abundances and distributions required by larval cod.
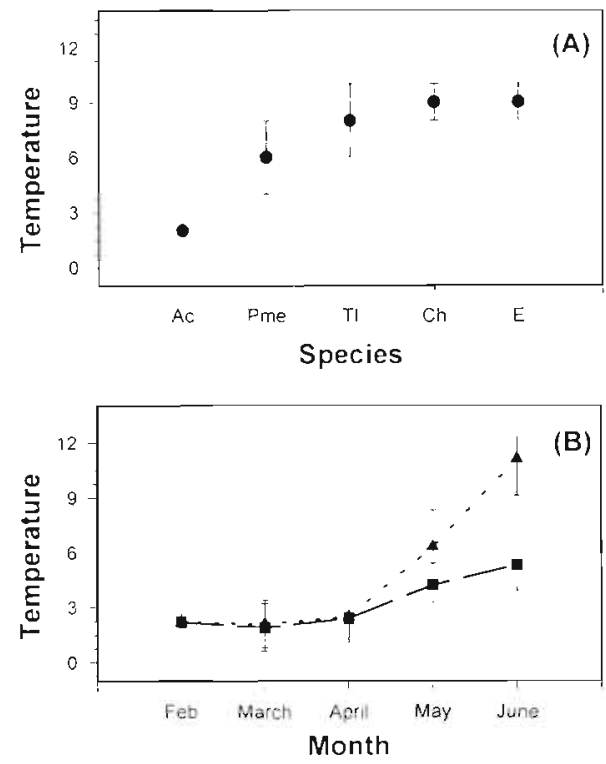

Fig. 9. (A) Midpoint and range of temperatures of maximum abundance of nauplii of 5 species of copepods in the Baltic Proper Ac: Acartia spp.; Pme: Pseudocalanus minutus elongatus; Tl: Temora longicornis; Ch: Centropages hamatus; E: Eurytemora spp.. Data from Hernroth \& Ackefors $(1979 ; \mathrm{p} 50)$. (B) Mean and SD of water temperatures near Bornholm Basin (area bounded by $55^{\circ} 25^{\prime} \mathrm{N}$ and $55^{\circ} 00^{\prime} \mathrm{N}$ and $16^{\circ} 01^{\prime} \mathrm{E}$ and $15^{\circ} 28^{\prime} \mathrm{E}$ ), as archived in the ICES hydrographic data base Data are monthly means of all observations recorded between 1960 and 1994 within the $5 \mathrm{~m}$ depth interval centred at $2.5 \mathrm{~m}$

(A) and within the $10 \mathrm{~m}(\mathbf{\square})$ depth interval centred at $30 \mathrm{~m}$

Nevertheless, these studies clearly demonstrate some important patterns in the eastern Baltic plankton that may be relevant to larval and pelagic 0-group cod ecology. First, nauplii of all copepod species are most abundant from March to June (Hernroth \& Ackefors 1979), and the biomass of crustacean zooplankton in the Baltic Proper peaks in August (HELCOM 1990). Second, Hernroth \& Ackefors (1979) observed a distinct seasonality in the occurrence of nauplii of different species (i.e. Acartia spp., Pseudocalanus minutus, Temora longicornis, Centropages hamatus, and Eurytemora spp.), which, according to these authors, is correlated with water temperature (Fig. 9). Hence the timing of cod spawning (see above) indicates that larvae and 0 -groups will, on average, occur in the water colurm coincident with peak prey abundance.

Third, the vertical distribution of copepods generally coincides with the vertical distribution of post yolk sac cod larvae. Within each of the 3 main eastern Baltic spawning areas, Ciszewska (1990) showed that during 1979 to 1983 the spring abundance of copepod nauplii, copepodite stages I. to $\mathrm{V}$ and adult copepods in the 0 to $25 \mathrm{~m}$ layer are 5 - to 10 -fold higher (30 to $50 \mathrm{ind}^{\mathrm{l}^{-1}}$ ) than in samples from 25 to $50 \mathrm{~m}$ and $50 \mathrm{~m}$ to the bottom 
(mean abundance $=4$ to 10 ind. $\mathrm{l}^{-1}$ ). During summer, copepod vertical distributions and concentrations change. Surface layer copepod concentrations are 5 to 10 ind $\mathrm{l}^{-1}$ and mid-depth concentrations are 10 to 20 ind. $\mathrm{l}^{-1}$. This vertical distribution is consistent with observations of Pseudocalanus minutus and Acartia bifilosa in Gdansk Bay (Ciszewski \& Witek 1977) which showed that peak concentrations $(5$ to 15 ind. $\left.\mathrm{l}^{-1}\right)$ were located at mid-depth and descended to deeper water as the summer progressed. By comparison, the depths of peak abundance of cod larvae have been reported to be 20 to $30 \mathrm{~m}$ (Wieland \& Zuzarte 1991), 30 to $60 \mathrm{~m}$ (Poulsen 1931), 30 to $50 \mathrm{~m}$ (Gronkjøer et al. 1995), 40 to $65 \mathrm{~m}$ (Müller 1988), and 70 to $80 \mathrm{~m}$ (Wieland \& Zuzarte 1991).

Fourth, the point estimates of zooplankton abundance reported by Ciszewska (1990) and Ciszewski \& Witek (1977) suggested that larvae and 0-groups may experience sufficient prey to grow at rates similar to cod in other regions. For example, the abundance of one potential prey species (Pseudocalanus minutus) at mid-depth was similar to that which produced larval cod feeding rates equal to 40 to $70 \%$ of maximum feeding rates observed in laboratory experiments (MacKenzie \& Kiørboe 1995, Munk 1995), and which give fast growth in large mesocosm studies (van der Meeren \& Naess 1993, Folkevord et al. 1994). In addition, Krajewska-Sołtys \& Linkowski (1994) indicated that the abundance of copepod nauplii and cope. podites is probably sufficient to ensure that starvation will not be an important mortality source in the Baltic Sea. Other prey species, small-scale prey patchiness (Owen 1989) and turbulent motion (Rothschild \& Osborn 1988, Sundby et al. 1994, MacKenzie \& Kiørboe 1995) would also occasionally increase feeding opportunities for cod larvae in the Baltic Sea.

Fifth, Ciszewska's (1990) data show that the intermediate layer $(25$ to $50 \mathrm{~m}$ ) of the Bornholm Basin contained about twice as many copepods in summer as the 2 other spawning areas (Gotland Basin, Gdansk Basin). Surface layer copepod abundances, however, were similar during summer at all 3 sites. These data suggest that, during the years of Ciszewska's (1990) study, larval cod in the Bornholm Basin may have experienced better feeding conditions than in the other spawning areas. Spatial and temporal patterns such as these require more investigation to determine their potential impacts on larval and pelagic 0-group cod growth.

Lastly, some long-term monitoring data (Kostrichkina et al. 1985, Renk et al. 1985, HELCOM 1990) showed that mesozooplankton biomass in the eastern and southeastern parts of the Baltic Proper has increased about 2- to 3 -fold from 1948 to 1987 , and that some major trophic components have changed during the same time period. For example, in August during the years 1960 to 1980 , the proportion of herbivorous mesozooplankton increased from ca 28 to $50 \%$ of total mesozooplankton biomass, while that for omnivorous mesozooplankton decreased from ca 60 to $20 \%$. Trends since 1980 appear to have reversed (HELCOM 1990). The causes for these trends are not clear but are probably related to increasing eutrophication of the Baltic Sea (HELCOM 1990), hydrographic-climatic interactions (e.g. Kostrichkina et al. 1985, Viitasalo et al. 1994) and other factors.

It is unclear, however, if these changes in zooplankton abundance and species composition have affected larval and pelagic 0-group growth. In addition, the long-term changes in proportions of omnivorous and herbivorous zooplankton that have occurred in the eastern Baltic Sea (HELCOM 1990) may have induced variability in growth and survival of larval and pelagic 0 -group cod via changes in plankton biochemical composition (Kaitaranta et al. 1986) and nutritional quality (Ferron \& Leggett 1994, Jonasdottir et al. 1995, St. John \& Lund 1996). The mechanisms involved, the directions of any changes in cod condition, and how these changes might affect cod survival are presently unclear but advances in biochemical means of assessing growth and condition in larval fish (Ferron \& Leggett 1994, St. John \& Lund 1996) should help to identify these in the future.

\section{PHYSICAL MECHANISMS INFLUENCING FOOD AVAILABILITY AT SMALL AND INTERMEDIATE SCALES}

Seasonally and spatially averaged summaries of zooplankton distributions such as those cited above overlook smaller scale variability in food conditions which can affect distributions of larval and 0-group fish (St. John et al. 1992. Munk et al. 1995) and feeding and growth rates (Lasker 1975, Bailey et al. 1995). Several physical processes (e.g. upwelling fronts, storms, breaking internal waves, plumes, and topographically induced eddies) operate at small to intermediate temporal and spatial scales (e.g. days to weeks and meters to kilometers) and can result in increased production or aggregation of larval and juvenile prey. For example, high biomass of plankton has been found at frontal zones created by wind induced upwelling events (Kahru et al. 1986, Raid 1989). In addition, increased concentrations of phytoplankton and zooplankton, as well as increased zooplankton production, have been found in regions where the permanent halocline ( 60 to $70 \mathrm{~m}$ depth) and summer thermocline (20 $\mathrm{m}$ depth) interact with bottom topography (e.g. slopes, banks; Raid 1989, St. John et al. 1995). Sprat larvae have been 

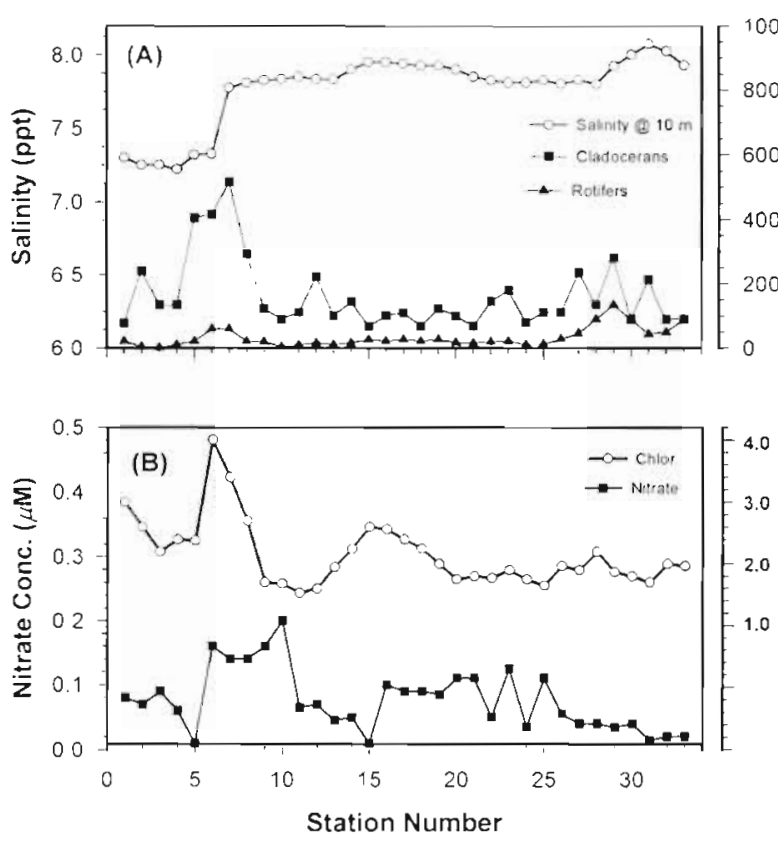

Fig. 10. Horizontal distributions along a NNW-SSE transect through the Bornholm Basin, 6 August 1984. (A) Salinity at $10 \mathrm{~m}$, biomass of the cladocerans and rotifers in the upper $10 \mathrm{~m}$ layer. (B) Surface (1 m) concentrations of nitrate $(N, \mu M)$, and chlorophyll a (chlor.) as extracted from water samples (Kahru et al. 1986). Data reproduced with permission from M. Kahru and Elsevier Science Publishers

found in these regions in association with aggregations of their principal prey Temora longicornis (Raid 1989).

Wind-induced surface circulation also produces enhanced feeding opportunities for cod and other fish larvae. For example, a surface flow interacting with Baltic discharge appears to produce an eddy-like circulation around Bornholm Basin (Kahru et al. 1986, Raid 1989). Increased abundance of cladocerans and rotifers has been found in one of these eddies, and high chlorophyll a and nitrate concentrations have been measured at its perimeter (Fig. 10). If such eddies are anti-cyclonic, as suggested by density contours (Figs. 11 \& 12), then eggs, larvae and prey can become concentrated in this region (Fig. 12).

The contribution of processes at small and intermediate scales (e.g. eddies, thermoclines, upwelling zones) to growth and condition of larval and 0-group cod is presently unknown for Baltic cod larvae and juveniles. In other regions (e.g. North Sea), cod larvae and pelagic 0 -group are more abundant at frontal zones than elsewhere (Munk et al. 1995), and their condition is better here than at neighboring sites (St. John \& Lund 1996). In the Baltic Sea, prey aggregating mechanisms at these scales are more ephemeral (Kahru et al. 1984) than tidal fronts because the large-
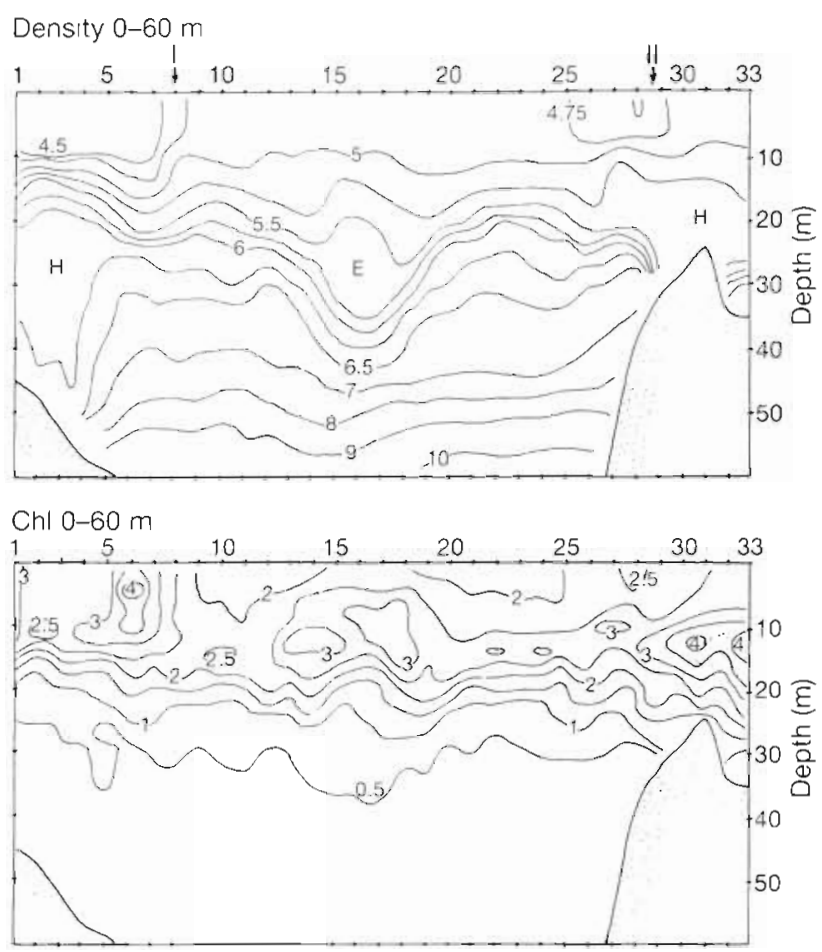

Fig. 11. Vertical distributions of density (sigma-t units) and chlorophyll a (mg m ${ }^{-3}$ ) on the transect, 6 August 1984. Arrows point to the frontal structures labeled I and II. An eddy-like deformation of the thermocline (E) and 2 bottom-mixed homogeneous water masses $(\mathrm{H})$ near shallow banks are labeled. Note the chlorophyll maximum in the low-salinity side of front $I$ and another maximum above one of the bottommixing areas. Contour interval is 0.5 for chlorophyll, 0.25 for the sigma-t range 4.5 to 6.5 and 1.0 for the sigma-t range 7 to 10 (Kahru et al. 1986). Data reproduced with permission of $M$. Kahru and Elsevier Science Publishers

scale surface circulation (Moller \& Hansen 1994) and the intermediate scale circulation (eddies, fronts, Langmuir circulations; e.g. Kahru et al. 1986) are highly dependent on wind and other meteorological variables (freshwater runoff, solar radiation; see also Viitasalo et al. 1994). Hence prey patches in the Baltic Sea form and disperse more frequently and at less predictable locations than in more persistent oceanographic regimes (e.g. tidal and topographically induced fronts; Bowers \& Simpson 1987, Wolanski \& Hamner 1988)

For this reason, we expect that the hydrographic conditions of the Baltic Sea will result in larval distributions frequently becoming uncoupled from those of their prey, thereby making it more difficult to relate cod growth and condition to intermediate scale physical features in the Baltic Sea than in tidally influenced areas. However, if the physical mechanisms responsible for the occurrence and persistence of such features in the Baltic Sea can be identified, it should be possible 

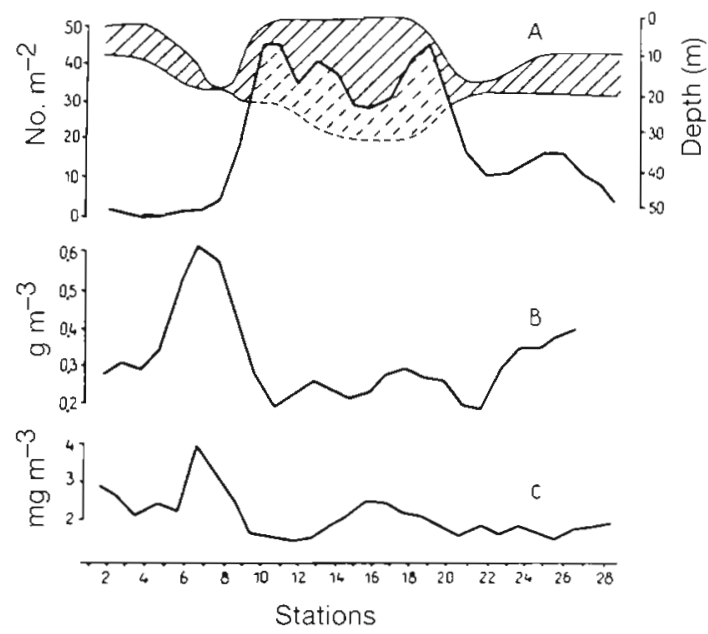

Fig. 12. Mean abundance of (A) sprat eggs and larvae, (B) zooplankton biomass, and (C) chlorophyll a concentration at stations along a NNW-SSE transect over the Bornholm Basin. Striped zone on panel A indicates location of layer with temperature 10 to $16^{\circ} \mathrm{C}$. Distance between stations: 1.5 nautical miles (Raid 1989). Data reproduced with permission of T. Raid and the General Secretary, ICES, Copenhagen, Denmark

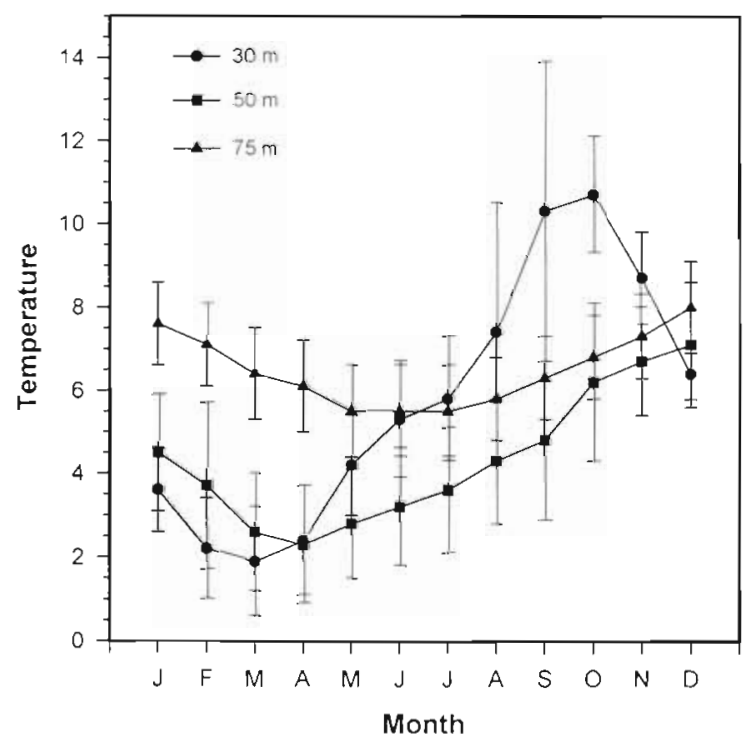

Fig. 13. Mean and SD of water temperatures near Bornholm Basin (area bounded by $55^{\circ} 25^{\prime} \mathrm{N}$ and $55^{\circ} 00^{\prime} \mathrm{N}$ and $16^{\circ} 01^{\prime} \mathrm{E}$ and $15^{\circ} 28^{\prime} \mathrm{E}$ ). All data are from ICES hydrographic data base. Data are monthly means of all observations recorded between 1960 and 1994 within the $10 \mathrm{~m}$ depth intervals centred at 30 . 50 and $75 \mathrm{~m}$

to construct physically based models which estimate their location, intensity, and frequency (e.g. de Young \& Davidson 1994)

Food availability will also be affected by centimetrescale water motion (Rothschild \& Osborn 1988). A num- ber of studies indicate that turbulence at these scales has both beneficial and detrimental effects on food ingestion rate by planktonic predators (reviewed by Kiørboe 1993), including larval cod (Sundby et al. 1994, MacKenzie \& Kiorboe 1995). We anticipate that the effect of turbulence on ingestion rates will be most evident in high-mixing regions of the Baltic Sea such as those associated with topographically induced current shear (Prandke \& Stips 1992) or frontal circulations. By comparison, turbulence generated by wind is unlikely to greatly affect either encounter rates or pursuit success (Mackenzie et al. 1994). This prediction is based on the long-term mean spring-summer wind speed $(7.5$ $\mathrm{m} \mathrm{s}^{-1}$; Moller \& Hansen 1994) recorded at Sprogø, western Baltic Sea and the frequent occurrence of larvae below the thermocline (Müller 1988, Wieland \& Zuzarte 1991) where the influence of wind on turbulence levels will be small (MacKenzie \& Leggett 1993)

\section{WATER TEMPERATURE, EGG DEVELOPMENT AND LARVAL GROWTH RATES}

As with all poikilotherms, water temperature has a major influence on development and growth rates of cod eggs and larvae. Average water temperatures experienced by cod eggs during development are 5.5 to $6^{\circ} \mathrm{C}$ (Fig 13), assuming peak spawning occurs on Day 156, and that eggs are located at $75 \mathrm{~m}$ depth. At these temperatures, eggs require $16 \mathrm{~d}$ to hatch (Wieland et al. 1994). Although the peak in spawning of Baltic cod is highly variable, eggs spawned at different times should develop at similar rates due to the relatively minor changes in deep water temperatures.

Growth rates for eastern Baltic cod larvae have not yet been estimated. While rates could be obtained by extrapolating information from other areas to the eastern Baltic population, this approach could lead to misinterpretations because growth rates vary with local food conditions and also vary genetically (Suthers et al. 1989, 1992, Blom et al. 1994). In addition, temperatures experienced by cod larvae in the eastern Baltic Sea are difficult to estimate because of variability in spawning time and larval vertical distributions. The strongest prediction we can make at this time is that, given sufficient prey, larval feeding and growth rates should be higher later in the year than earlier (Houde 1989, MacKenzie et al. 1990) because of higher temperatures (Fig 13).

The influence of temperature on growth therefore needs further study, particularly given the wide range of temperatures to which larvae in the eastern Baltic Sea are exposed, and the potential for global warming to affect long-term temperatures in the Baltic (Matthaus \& Franck 1992). Variability in the timing of spawning coupled with seasonal warming is likely 
responsible for interannual differences in end-of-year estimates of size of 0-group cod (Kondratovich \& Lablaika 1989). Future temperature-related studies might include investigating temperature effects in mesocosm or laboratory studies, deriving otolith- and length-based growth rates from field collected specimens, and reconstructing environmental conditions experienced by larvae from otolith microchemistry (Campana et al. 1995, Townsend et al. 1995).

Water temperature also appears to have indirect influences on recruitment in some cod populations. For example, recruitment in northeast Arctic cod (as determined by abundance at age $3+$ ) is more likely to be above-average in years when the mean temperature in Arcto-Norwegian waters during the egg-larval phase (March and April) is $>3^{\circ} \mathrm{C}$ (Ellertsen et al. 1989). This finding may be partly due to detrimental effects of low temperature on larval growth and survival (Laurence 1978, Campana \& Hurley 1989). It is unknown whether significant relationships exist between recruitment and temperatures experienced during the egg and larval stages of eastern Baltic cod, but this issue should be investigated further.

\section{CONCLUSION}

We have summarized some of the eastern Baltic cod literature pertaining to the survival and growth of eggs and larvae. Several data gaps and opportunities for further research have been identified. One of the most critical is our lack of understanding of factors affecting the timing and duration of spawning, and the seasonality of other components of the Baltic ecosystem (i.e. oxygen concentrations, predation, prey production rates) that affect egg and larval survival. In particular, until the seasonal distribution of spawning activity is better described, it will be difficult to relate seasonal and interannual variability in environmental conditions to egg and larval growth and survival.

We note that some important variables affecting longterm reproductive and recruitment success of Baltic cod (e.g. oxygen concentration, cod population structure, predator abundances) are to some extent already within human control. These variables can potentially be altered in ways that would benefit the cod population (e.g. reducing nutrient loads to improve oxygen conditions, changing fishing practices to affect population age structure and spawning time). However, successfully implementing these changes will require a more thorough understanding of linkages between cod, its ecosystem and Baltic fishing activities than is presently available. Hopefully such information will be forthcoming soon so that it can be incorporated into the future management of both cod and its environment.
Acknowledgements. We thank O. Vagn Olsen (Danish Institute for Fisheries Research) for extracting Bornholm Basin water temperature data from the ICES hydrography data base, and P. Gronkjœr (Institute for Biological Sciences, University of Arhus, Denmark), M. Kahru (Scripps Institution of Oceanography, University of (alifornia at San Diego, USA). T. Linkowskı (Sea Fisheries Institute, Gdynia, Poland), and T Raid (Estonian Marine Institute, Tallinn) for kindly sharing data with us. We have benefited greatly from conversations held with numerous colleagues in the Baltic fisheries and oceanographic communities. We also thank our reviewers for comments on an earlier version of the manuscript. This work was supported by funding from the EU (grant no. AIR2 94 1226), and from the Danish National Science Research Council (BRM)

\section{LITERATURE CITED}

Ådlandsvik B, Sundby S (1994) Modelling the transport of cod larvae from the Lofoten area. ICES Mar Sci Symp 198 $379-392$

Aro E (1989) A review of fish migration patterns in the Baltic Rapp PV Réun Cons Int Explor Mer 190:72-96

Aro E, Myrberg K, Salli A, Sonnichsen T (1991) Estimation of Baltic cod eggs and larvae drift by two-layer flow model with variable winds. ICES Comm Meet 1991/J:15

Bagge O (1981) Demersal fishes. In: Volpio A (ed) The Baltic Sea. Elsevier Science Publishers, Amsterdam, p 311-333

Bagge O, Bay J, Steffensen E (1993) Fluctuations in abundance of the Baltic cod (Gadus morhua) stock in relation to changes in environment and the fishery. NAFO Sci Coun Stud 18:35-42

Bagge O. Steffensen E (1989) Stock identification of demersal fish in the Baltic. Rapp PV Réun Cons Int Explor Mer 190 $3-16$

Bagge O, Steffensen E (1991.) The condition factor in relation to maturity and filling of stomach in cod (Sub-division 25) ICES Comm Meet 1991/J:13

Bagge O, Thurow F, Steffensen E, Bay J (1994) The Baltic cod Dana 10:1-28

Bailey KM, Canino MF, Napp JM, Spring SM, Brown AL (1995) Contrasting years of prey lovels, feeding conditions and mortality of larval walleye pollock Theragra chalcogramma in the western Gulf of Alaska. Mar Ecol Prog Ser 119:11-23

Bainbridge V, McKay BJ (1968) The feeding of cod and redfish larvae. Int Comm Northwest Atl Fish Spec Publ 7 $187-218$

Berner M, Vaske B (1981) Sex ratio and sexual maturity of cod in the Baltic (Subdivisions 22-25). ICES Comm Meet $1981 / \mathrm{J}: 16$

Birjukov NP (1969) Spawning communities of Baltic cod and extent of their mixing. Comm Meet ICES 1969/F:7

Blom G, Svåsand T, Jørstad KE, Otterå H, Paulsen Ol, Holm JC (1994) Comparative survival and growth of two strains of Atlantic cod (Gadus morhua) through the early life stages in a marine pond. Can J Fish Aquat Sci 51: 1012-1023

Brander K (1993) Companson of spawning characteristics of cod (Gadus morhua) stocks in the North Atlantic. NAFO Sci Coun Stud 18:13-20

Brander K (1994) The location and timing of cod spawning around the British Isles. ICES J Mar Sci 51:71-89

Brander K. Houghton RG (1982) Predicting the recruitment of North Sea plaice from egg surveys. ICES Comm Meet 1982/G:5 
Bowen A, Griffin D, Hazen DG, Matheson SA, Thompson KR (1995) Shipboard nowcasting of shelf circulation. Cont Shelf Res 15:115-128

Bowers D. Simpson JH (1987) Mean position of tidal fronts in European-shelf seas. Cont Shelf Res 7:35-44

Campana SE. Hurley PCF (1989) An age- and temperaturemediated growth model for cod (Gadus morhua) and haddock (Melanogrammus aeglefinus) larvae in the Gulf of Maine. Can J Fish Aquat Sci 46:603-613

Campana SE, Gagné JA, McLaren JW (1995) Elemental fingerprinting of fish otolths using ID-ICPMS. Mar Ecol Prog Ser 122:115-120

Chambers RC, Leggett WC, Brown JA (1989) Egg sıze, temale effects, and the correlations between early life history traits of capelin, Mallotus villosus: an appraisal at the individual level. Fish Bull 87:515-523

Ciszewska I (1990) Quantitative changes in the Baltic mesozooplankton on the basis of montoring within the 1979-1983 period. Oceanologia 29:77-90

Ciszewski P (1985) Long-term trends in mesozooplankton bromass development in the southern Baltic. Oceanologia 22:63-70

Ciszewski P, Witek Z (1977) Production of older stages of copepods Acartia bifilosa Giesb. and Pseudocalanus elongatus Boeck in Gdansk Bay. Pol Arch Hydrobiol 24(4): $449-459$

de Young B, Davidson F (1994) Modelling retention of cod eggs and larvae (Gadus morhua L.) on the Newfoundland shelf. ICES Mar Sci Symp 198:346-355

Dickson R, Brander K (1993) Effects of a changing windfield on cod stocks of the North Atlantic. Fish Oceanogr 2:124-153

Economou AN (1991) Food and feeding ecology of five gadoid larvae in the northern North Sea.J Cons Int Explor Mer 47:339-351.

Ellertsen B, Fossum P, Solemdal P, Sundby S (1989) Relation between temperature and survival of eggs and first-feeding larvae of northeast Arctic cod (Gadus morhua L.). Rapp PV Réun Cons Int Explor Mer 191:209-219

Ferron A, Leggett WC (1994) An appraisal of condition measures for marine fish larvae. Adv Mar Biol 30:217-303

Folkvord A, Øiestad V, Kvenseth PG (1994) Growth patterns of three cohorts of Atlantic cod larvae (Gadus morhua L.) studıed in a macrocosm. ICES J Mar Sci 51:325-336

Frank KT (1991) Predicting recruitment variation from year class specific vertebral counts: an analysis of the potential and a plan for verification. Can J Fish Aquat Sci 48: $1350-1357$

Funkquist L (1993) An operational Baltic Sea circulation model. Swedish Meteorological and Hydrological Institute Oceanography Report No 18, Norrköping

Grauman GB (1965) Changes in the egg size of cod (Gadus morhua calliarias L.) within the spawning period. ICES Comm Meet 1965/Baltic-Belt Seas Committee Paper No. 47

Grønkjœr P, Möllman C, Voss R (1995) Abundance and distribution of larval cod (Gadus morhua) in the Bornholm Basin. ICES Comm Meet 1995/J:24

Hansson S, Rudstam LG (1990) Eutrophication and Baltic fish communities. Ambio 19:123-125

Heath MR (1993) An evaluation and review of the ICES herring larval surveys in the North Sea and adjacent waters. Bull Mar Sci 53:795-817

Heessen HJL, Rijnsdorp AD (1989) Investigations on egg production and mortality of cod (Gadus morhua L.) and plaice (Pleuronectes platessa L.) in the southern and eastern North Sea in 1987 and 1988. Rapp PV Réun Cons Int Explor Mer 191:15-20
HELCOM (1990) Baltic Sea Environment Proceedings. Second periodic assessment of the state of the marine environment of the Baltic Sea, 1984-1988; background document No 35 B. HELCOM, Helsinki, p 180-210

Hernroth L, Ackefors H (1979) The zooplankton of the Bultic proper. A long-term investigation of the fauna, its biology and ecology. Fish Bd Swed Inst Mar Res Rep No 2

Hinrichsen HH, Lehmann A, St. John M, Brügge B (1995) Larval druft and retention: Baltic cod, a modeling approach. ICES Comm Meet 1995/L.:28

Houde ED (1989) Comparative growth, mortality, and energetics of marine fish larvae: temperature and implied lattudinal effects. Fish BuIl US 87:471-495

Hutchings JA, Myers RA (1993) Effect of age on the seasonality of maturation and spawning of Atlantic cod, Gadus morhua, in the Northwest Atlantic. Can J Fish Aquat Sci 50:2468-2474

Hutchings JA, Myers RA (1994a) What can be learned from the collapse of a renewable resource? Atlantic cod, Gadus morhua, of Newfoundland and Labrador. Can J Fish Aquat Sci 51:2126-2146

Hutchings JA, Myers RA (1994b) Timing of cod reproduction: interannual variability and the influence of temperature. Mar Ecol Prog Ser 108:21-31

ICES (1993) Report of the Working Group on the Assessment of Demersal Stocks in the Baltic. ICES Comm Meet 1993/ Assess: 16

ICES (1994a) Report of the Working Group on the Assessment of Demersal Stocks in the Baltic. ICES Comm Meet 1994/ Assess: 17

ICES (1994b) Spawning and life history information for North Atlantic cod stocks. (Brander $\mathrm{K}$, ed). ICES Coop Res Rep 205

ICES (1994c) Report of the Working Group on the Assessment of Demersal Stocks in the North Sea and Skagerrak. ICES Comm Meet/Assess: 6

ICES (1994d) Report of the ICES/GLOBEC Cod and Clumate Change AGGREGATiON Workshop, Charlottenlund, Denmark, August 22-24, 1994. ICES Comm Meet 1994/ A: 10

i Jakupsstovu SH, Reinert J (1994) Fluctuations in the Faroe Plateau cod stock. ICES Mar Sci Symp 198:194-211

Johansen AC (1926) On the remarkable quantities of haddock in the Belt Sea during the winter of 1925-26, and causes leading to the same. J Conseil I(2):140-156

Jónasdóttir SH, Fields D, Pantoja S (1995) Copepod egg production in Long Island Sound, USA, as a function of the chemical composition of seston. Mar Ecol Prog Ser 119 : $87-98$

Kahru M, Elken J, Kotta I, Simm M, Vilbaste K (1984) Plankton distributions and processes across a front in the open Baltic Sea. Mar Ecol Prog Ser 20:101-111

Kahru M, Nomman S, Simm M, Vilbaste K (1986) Plankton distributions and processes in the Baltic boundary zones. In: Nihoul JCJ (ed) Marine interfaces ecohydrodynamics. Elsevier Oceanographic Series No 42. Elsevier Science Publishers, Amsterdam, p 273-294

Kaitaranta JK, Lınko RR, Vuorela R (1986) Lipids and fatty acids in plankton from the Finnish coastal waters of the Baltic Sea. Comp Biochem Physiol 85B(2):427-433

Kändler R (1938) Untersuchungen über das Laichen des Ostseedorsches im Herbst. Kieler Meeresforsch [I:271-292

Kändler R (1949) Untersuchungen über den Ostseedorsch während der Forschungsfahrten mit dem RFD 'Poseidon' in den Jahren 1925-1938. Ber Dt Wiss Kommn Meeresforsch XI: $137-245$

Kane J (1984) The feeding habits of co-occurring cod and 
haddock larvae. Mar Ecol Prog Ser 16:9-20

Kiorboe T (1993) Turbulence, phytoplankton cell size, and the structure of pelagic food webs. Adv Mar Biol 29:1-72

Kjesbu OS, Klungsøyr J, Kryvi H, Withames PR, Greer Walker M (1991) Fecundity, atresia, and egg size of captive Atlantic cod (Gadus morhua) in relation to proximate body composition. Can J Fish Aquat Sci 48(12):2333-2343

Kjesbu OS, Kryvi H, Sundby S, Solemdal P (1992) Buoyancy variations in eggs of Atlantic cod (Gadus morhua L.) in relation to chorion thickness and egg size: theory and observations. J Fish Biol 41:581-599

Kjesbu OS (1994) Time of start of spawning in Atlantic cod (Gadus morhua) females in relation to vitellogenic oocyte diameter, temperature, fish length and condition. J Fish Biol 45:719-735

Knutsen GM. Tilseth S (1985) Growth, development, and feeding success of Atlantic cod larvie Gadus morhua, related to egg size. Trans Am Fish Soc 114:507-511

Kondratovich EJ, Lablaika I (1989) Abundance and ecology of young cod in the Eastern Baltuc in 1980-1987. Rapp PV Réun Cons Int Explor Mer 190:58-62

Kosior M. Strzyzewska K (1979) Fecundity of Baltic cod. ICES Comm Meet 1979/J:10

Köster FW, Schnack D (1994) The role of predation on early life stages of cod in the Baltic. Dana 10:179-201

Kostrichkina EM, Yurkovskis AK, Bersin'sh V, Line R Ya (1985) On the influence of oceanographic conditions on the long-term abundance dynamics of zooplankton in the Gulf of Riga. ICES Comm Meet 1985/L:5

Krajewska-Soltys A, Linkowski T (1994) Densities of potential prey for cod larvae in deep-water basins of the southern Baltic. ICES Comm Meet 1994/J:17

Krauss W, Brügge B (1991) Wind-produced water exchange between the deep basins of the Baltic Sea. J Phys Oceanogr 21:373-384

Krenkel K (1981) Über das Vorkommen der Eier und Larven von Sprott (Sprattus) und Dorsch (Gadus morhua) in der Ostsee in den Jahren 1.977-1980. Fisch Forsch 19(2): $31-36$

Kullenberg G, Jacobsen TS (1981) The Baltic Sea: an outline of its physical oceanography. Mar Poll Bull 12(6):183-186

Lasker R (1975) Field criteria for the survival of anchovy larvae: the relations between inshore chlorophyll maximum layers and successful first feeding. Fish Bull US 73 $4.53-462$

Laurence GC (1978) Comparative growth, respiration and delayed feeding abilities of larval cod (Gadus morhua) and haddock (Melanogrammus aeglefinus) as influenced by temperature during laboratory studies. Mar Biol 50:1-7

Lehmann A (1995) A three-dimensional baroclinic eddyresolving model of the Baltic Sea. Tellus 47 A: 1013-1031

Lindsey CC (1988) Factors controlling meristic variation. In Hoar WS, Randal DJ (eds.) Fish physiology, Vol XI(B) Academic Press, Toronto, p 197-274

Linkowski TB, Kowalewska-Pahlke M (1993) Growth of juvenile Baltic cod estimated from daily growth increments in otoliths. ICES Comm Meet 1993/J:19

Mackenzie BR, Kiørboe T (1995) Encounter rates and swimming behaviour of pause-travel and cruise larval fish predators in calm and turbulent laboratory environments. Limnol Oceanogr 40:1278-1289

Mackenzie BR, Leggett WC (1993) Wind-based models for estimating the dissipation rates of turbulent energy in aquatic environments: empirical comparisons. Mar Ecol Prog Ser 94:207-216

MacKenzie BR, Leggett WC, Peters RH (1990) Estimating larval fish ingeston rates: can laboratory denved values be reli- ably extrapolated to the wild? Mar Ecol Prog Ser 67:209-225

MacKenzie BR, Miller TJ, Cyr S, Leggett WC (1994) Evidence for dome-shaped relationship between turbulence and larval fish ingestion rates. Limnol Oceanogr 39:1790-1799

Marteinsdottir G, Jonasdottir S, Thorsteinsson V (1993) Seasonal variation in egg size and its influence on egg and larval qualities of cod at lceland. ICES 1993 Symposium on Cod and Climate Change Paper No 28

Matthaus W (1993) Major inflows of highly saline water into the Baltic Sea-a review. ICES Comm Meet 1993/C.52. Session $\mathrm{V}$

Matthaus W, Franck H (1992) Characteristics of major Baltic inflows - a statistical analysis. Contl Shelf Res 12: $1375-1400$

Moller JS, Hansen IS (1994) Hydrographic processes and changes in the Baltic Sea. Dana 10:87-104

Müller A (1988) Vertical distribution of ichthyoplankton in the Bornholm Basın. Kieler Meeresforsch, Sonderh 6:341-347

Müller A, Bagge $O$ (1984) The occurrence of cod eggs and the size of fish eggs in Bornholm Basin. ICES Comm Meet $1984 / \mathrm{J}: 17$

Müller A, Pommeranz (1984) Vertical distribution of fish eggs in the Bornholm Basin. Int Symp Early Life History of Fishes and 8th Annual Larval Fish Conference, Vancouver

Munk P (1995) Foraging behaviour of larval cod (Gadus morhual influenced by prey density and hunger. Mar Biol 122:205-212

Munk P, Larsson PO, Danielsen D, Moksness E (1995) Larval and juvenile cod (Gadus morhua) concentrated in the highly productive areas of a shelf break front. Mar Ecol Prog Ser 125:21-30

Nissling A, Kryvi H, Vallin L (1994) Variation in egg buoyancy of Baltic cod Gadus morhua and its implications for egg survival in prevailing conditions in the Baltic Sea. Mar Ecol Prog Ser 110:67-74

Owen RW (1989) Microscale and finescale variations of small plankton in coastal and pelagic environments. J Mar Res $47: 197-240$

Pedersen T (1984) Variation of peak spawning of Arcto-Norwegian cod (Gadus morhua L.) during the time period 1929-1982 based on indices estimated from fishery statistics. Flødevigen Rapportser 1:301-316

Plikshs M, Kalejs M, Grauman G (1993) The influence of environmental conditions and spawning stock size on the yearclass strength of the eastern Baltic cod. ICES Comm Meet 1993/J:22

Poulsen EM (1931) Biological investigations upon the cod in Danish waters. Medd Dan Fisk Havunders Ser Fisk IX(1): $1-1.48$

Prandke $H$, Stips $A$ (1992) On the nature of near-bottom mixing in Baltic water basins. ICES Comm Meet C:25

Raid T. (1989) The influence of hydrodynamic conditions on the spatial distribution of young fish and their prey organisms. Rapp PV Réun Cons Int Explor Mer 190:166-172

Renk H, Nakonieczny J, Ochocki S, Gromisz S (1985) Longterm changes of phytoplankton and zooplankton biomass in southern Baltic. ICES Comm Meet 1985/L:28

Rose GA (1994) Cod spawning on a migration highway in the north-west Atlantic. Nature 366:458-461

Rothschild BJ, Osborn TR (1988) Small-scale turbulence and plankton contact rates. J Plankton Res 10:465-474

Solemdal P, Bergh, $\varnothing$. Finn RN, Fyhn HJ, Grahl-Nielsen $O$, Homme O, Kjesbu OS, Kjorsvik E, Opstad I, Skiftesvik AB (1992) The effects of maternal status of Arcto-Norwegran cod on egg quality and vitality of early larvae. II. Preliminary results of the experiment in 1992. ICES Comm Meet 1992/G:79 
Solemdal P, Kjesbu OS, Fonn S (1995) Egg mortality in recruit- and repeat-spawning cod-an experimental study. ICES Comm Meet 1995/G:35

St. John MA, MacDonald JS, Harrison PJ, Beamish RJ, Choromanski E (1992) The Fraser River Plume: some preliminary observations on the distribution of juvenile salmon, herring and their prey. Fish Oceanogr 1:153-162

St. John MA, Marinone SG, Stronach J, Harrison PJ, Fyfe J. Beamish RJ (1993) A horizontally resolving physicalbiological model of nitrate concentration and primary productivity in the Strait of Georgia. Can J Fish Aquat Sci 50; $1456-1466$

St. John M, Munk P, Bagge D(1995) The influence of hydrographic processes on plankton distribution and production in the Bornholm Basin, Baltic Sea. ICES Comm Meet 1995/ Q:5

St. John MA, Lund T (1996). Lipid biomarkers: linking the utilization of frontal plankton biomass to enhanced condition juvenile North Sea cod. Mar Ecol Prog Ser 131:75-85

Sundby M, Ellertsen B, Fossum P (1994) Encounter rates between first-feeding cod larvae and their prey during moderate to strong turbulence. ICES Mar Sci Symp 198: $393-405$

Suthers IM, Frank KT, Campana SE (1989) Spatıal comparison of recent growth in postlarval Atlantic cod (Gadus morhual off southwestern Nova Scotia: inferior growth in a presumed nursery area. Can J Fish Aquat Sci 46 (Suppl 1):113-124

Suthers IM, Fraser A, Frank KT (1992) Comparison of lipid, otolith and morphometric condition indices of pelagic juvenile cod Gadus morhua from the Canadian Atlantic. Mar Ecol Prog Ser 84:31-40

Townsend DW, Radtke RL, Malone DP, Wallinga JP (1995) Use of otolith strontium calcium ratios for hindcasting larval cod Gadus morhua distributions relative to water masses on Ceorges Bank. Mar Ecal Prog Ser 119:37-44

Trippel EA, Neilson JD (1992) Fertility and sperm quality of virgin and repeat-spawning Atlantic cod (Gadus morhua) and associated hatching success. Can J Fish Aquat Sci 49 (10): $2118-2127$

This review was submitted to the editor
Uzars D, Plıkshs M, Grauman G, Kalejs M, Baranova T (1991) Cod distribution and spawning in the Gotland Basin in the 1980s. ICES Comm Meet 1991/J:5

van der Meeren T, Næss T (1993) How does cod lGadus morhua) cope with variability in feeding conditions during early larval stages? Mar Biol 116:637-647

Viitasalo M, Katajisto T, Vuorinen I (1994) Seasonal dynamics of Acartia bifilosa and Eurytemora affinis (Copepoda: Calanoida) in relation to abiotic factors in the northern Baltic Sea. Hydrobiologia 292/293:415-422

Weber W (1.989) A rovinw of stock assessments of cod in the Baltic. Rupp PV Réun Cons int Explor Mer 190: $224-234$

Werner FW, Perry RI, Lough RG, Naıme CE (1996) Trophodynamic and advective influences on Georges Bank larval cod and haddock. Deep Sea Res II (in press)

Westerberg H (1994) The transport of cod eggs and larvae through Oresund. ICES Comm Meet 1994/Q:4

Westm L, Nissling A (1991) Effects of salinity on spermatozoa motility, percentage of fertilized eggs and egg development of Baltic cod (Gadus morhua), and implications for cod stock fluctuations in the Baltic. Mar Biol 108:5-9

Wieland K, (1988) Distribution and mortality of cod eggs in the Bornholm Basin (Baltic Sea) in May and June 1986. Kieler Meeresforsch Sonderh 6:331-340

Wieland K (1995) Einfluß der Hydrographie auf die Vertikalverteilung und Sterblichkeit der Eier des Ostseedorsches (Gadus morhua callarias) im Bornholmbecken, südliche zentrale Ostsee. PhD thesis, Institut für Meereskunde an der Christian-Albrechts-Universität, Kiel

Wieland $K$, Zuzarte $F$ (1991) Vertical distribution of cod and sprat eggs and larvae in the Bornholm Basin (Baltic Sea) 1987-1990. ICES Comm Meet 1991/J:37

Wieland K, Waller U, Schnack D (1994) Development of Baltic cod eggs at different levels of temperature and oxygen content. Dana 10:163-177

Wolanski E. Hamner WM (1988) Topographically controlled fronts in the ocean and their biological influence. Science 241:177-181

Manuscript first received: December 2, 1994

Revised version accepted: November 23, 1995 